\title{
RAJALLINEN TYÖMUISTI S2-OPPIJOIDEN PUHEENYMMÄRTÄMISVAIKEUKSIEN SELITTÄJÄNÄ
}

\author{
Saara Laakso, Soveltavan kielentutkimuksen keskus \\ (SOLKI)
}

\begin{abstract}
Tässä artikkelissa käsittelen työmuistin rajallisuuden ja aikuisten suomenoppijoiden puheenymmärtämisvaikeuksien yhteyttä tarkastelemalla oppijoiden kuuntelutehtäväsuorituksia ja niitä seuraavia stimulated recall - haastatteluja. Lisäksi selvitän, millaisilla muistitoiminnoilla oppijat kompensoivat työmuistin rajallisuutta ja helpottavat ymmärtämistä. Tutkimukseen osallistui 12 arabiankielistä alkeis- ja perustason aikuista suomenoppijaa, ja aineisto koostuu oppijoiden kuuntelutehtäväsuoritusten ja stimulated recall -haastattelujen videotallenteista.

Työmuistin rajallisuuden vaikutus ymmärtämisvaikeuksissa tuli esiin erityisesti silloin, kun yhteen sanaan tai ilmaukseen keskittyminen aiheutti edeltävien tai seuraavien sanojen unohtamista ja kun mielessä pidettävän puhejakson pituus ylitti osallistujan kapasiteetin. Osallistujat kompensoivat työmuistin rajallisuutta ja helpottivat ymmärtämistään ylhäältä alas -prosessoinnilla eli täydentämällä tekstiin jääneitä aukkoja säilömuistissa olevalla maailmantiedollaan ja kokemuksillaan.
\end{abstract}

Avainsanat: puheen ymmärtäminen, stimulated recall -menetelmä, suomi toisena kielenä, toisen kielen oppiminen, työmuisti

\section{JOHDANTO}

Toisen tai vieraan kielen opiskelu voi sisältää alkuvaiheessa monia turhauttavia hetkiä, kun puheen ymmärtäminen arkipäivän monimuotoisissa tilanteissa ei onnistu yhtä hyvin kuin opettajan selkeiden ohjeiden seuraaminen luokassa. Monet oppijat ajattelevat vaikeuden johtuvan siitä, että puhutaan liian nopeasti (ks. Laakso, 2015). Rostin ja Wilsonin (2013) mukaan puhenopeus on toisen kielen kuuntelijoilla yleinen ongelma,

Kirjoittajan yhteystiedot:

Saara Laakso

laaksonsaara@gmail.com mutta ymmärtämisen vaikeus ei välttämättä johdu nopeudesta vaan siitä, että oppijat eivät ole tottuneet purkamaan puhuttua kieltä tarpeeksi nopeasti. Puhujan puhenopeus ei ole aina nopeampaa kuin keskimääräinen puhe, vaan oppija ainoastaan kokee puheen nopeaksi. (Mt. s. 11.) Toisin sanoen oppijan kokemuksen taustalla on prosessoinnin hitaus verrattuna puhevirran etenemisnopeuteen. Mikäli puhevirran purku vaatii vielä paljon tarkkaavaisuutta, työmuisti kuormittuu nopeasti, ja puheesta jää osia purkamatta. Oppijoiden käsitykset vaikeuksien syistä antavat tärkeän näkökulman ymmärtämisongelmien tarkasteluun, mutta tätä näkökulmaa voi vielä laajentaa ja syventää kognitiivisia ilmiöitä kos- 
kevan tutkimustiedon avulla. Tässä artikkelissa tavoitteena on tarkastella sitä, miten oppijoiden kokemukset ja käsitykset ymmärtämisvaikeuksista kytkeytyvät tämänhetkiseen tutkimustietoon työmuistista toisen kielen omaksumisessa ja oppimisessa.

Oppijoiden kokemukset ja niiden pohjalta luodut käsitykset kertovat vaillinaisesti siitä, mitä pään sisällä tapahtuu, kun ymmärtäminen muuttuu vaikeaksi. Kokemusten taustalla olevat kognitiiviset ilmiöt voivat olla tuntemattomia niin oppijalle kuin opettajallekin. Opetuksen kehittämisen ja kohdentamisen kannalta olisi kuitenkin tärkeää, että opettajat tulisivat näistä ilmiöistä tietoisiksi. Etsimällä yhtymäkohtia oppijoiden raporteista ja kognitiivisista tutkimuksista voidaan nähdä, millaisina ymmärtämiseen vaikuttavat kognitiiviset ilmiöt, kuten muistin toiminnot, näyttäytyvät oppijoille ja miten he niitä kielentävät. Tästä on hyötyä opetuksen kohdentamisessa: kun ymmärretään perusteellisemmin vaikeuksien taustalla olevat syyt, on niihin helpompi tarttua myös opetustilanteessa.

Kun alkuvaiheen oppijalla vieraskielisen puhevirran prosessointi on hidasta ja kontrolloitua, kielitaidon kehittyessä prosessointi nopeutuu ja muuttuu vähitellen automaattiseksi, ja silloin sanojen ja sanaryppäiden tunnistus tapahtuu jo tiedostamatta (esim. Vandergrift \& Goh, 2012, s. 19-20). Koska työmuistissa puhetta voidaan käsitellä vain rajallinen määrä kerrallaan, puhevirran prosessoinnin nopeus määrittelee sen, pysyykö kuuntelija puhujan vauhdissa mukana vai ei. Rajallisella määrällä tarkoitetaan tyypillisesti noin neljää merkityksellistä yksikköä tai kiteytymää (esim. Cowan, 2014, s. 204; myös Wen, 2016, s. 12). Yksikköjen laajuus voi kuitenkin vaihdella sen mukaan, miten moneen merkitykselliseen osaan kuuntelija ryhmittelee kuulemansa kokonaisuuden. Kun kielitaito kasvaa, myös työmuistin yksiköt kasvavat: yksittäisten sanojen sijaan työmuistissa pys- tytään säilyttämään sanaryppäitä ja ryppäitä laajempiakin kokonaisuuksia. Sanaa laajempien kokonaisuuksien, sanaryppäiden, muodostamiseen käytetään tyypillisesti säilömuistissa olevaa tietoa (Baddeley, 2000, s. 419). Työmuistin rajallisuus näkyy myös siinä, että tieto säilyy työmuistissa vain muutamia sekunteja. Jos puheesta poimittuja pieniä tai isoja kokonaisuuksia ei saa pidetyksi mielessä niitä toistamalla, ne häipyvät pois. (Esim. Baddeley, 2000, s. 419; Baddeley, 2003, s. 191.) Tämä voi näkyä esimerkiksi siinä, että kun jää pohtimaan yhden sanan merkitystä, muut puheesta poimitut sanat ehtivät unohtua.

Tässä artikkelissa oppijoiden ymmärtämisvaikeuksien ja muistitoimintojen yhteyden käsittely pohjautuu analyysiin, joka on tehty kuuntelutehtäväsuoritusten havainnoinnin ja oppijoiden stimulated recall -haastattelujen pohjalta (ks. luku 3). Vastaan artikkelissa seuraaviin kysymyksiin:

1) Miten työmuistin rajallisuus tulee esiin oppijoiden kuuntelutehtäväsuorituksissa ja niitä reflektoivissa stimulated recall -haastatteluissa?

2) Millaisilla muistiin liittyvillä toiminnoilla kompensoidaan työmuistin rajallisuutta ja helpotetaan ymmärtämistä?

\section{TYÖMUISTI JA TOISEN KIELEN OPPIMINEN}

Käytän analyysissani teoreettisena pohjana Edward Wenin (2016) laatimaa viitekehystä työmuistin ja toisen kielen oppimisen yhteyden tutkimiseen (an integrated framework for working memory and SLA research). Englanninkielisten käsitteiden suomentamisen tukena olen käyttänyt kognitiivisen neurotieteen tutkijan Petri Paavilaisen (2016) kirjoittamaa Toimivat aivot - kognitiivisen neurotieteen perusteita -teosta. Wenin malli perustuu niille käsityksille työmuistista, jotka ovat yhdistettävissä ja joista ollaan eri koulukunnissa 
yhtä mieltä, ja sen tavoitteena on yhdistää työmuistitutkimuksen näkemykset ensi- ja toisen kielen tutkimuksen kanssa. Kahta eri tutkimusalaa yhdistävän viitekehyksen hän katsoo tuovan teoreettisia etuja, joita kumpikaan ala ei yksinään saavuttaisi (Wen, 2016, s. 87,90$)$.

Wen (2016, s. 80) määrittelee työmuistin toisen kielen tutkimuksessa

moninaisiksi kognitivisiksi mekanismeiksi ja toiminnoiksi, jotka vastaavat siitä, kuinka rajallista määrää kielellistä tietoa hetkellisesti säilytetään, haetaan ja ohjataan, jotta voidaan helpottaa toisen kielen oppimisen eri alueiden ja tehtävien omaksumista, esittämistä, prosessointia ja kehittymistä.

Märirtelmästä käy ilmi, kuinka työmuisti osallistuu monin tavoin kielellisen tiedon käsittelyyn mutta kuinka sen toiminta on myös rajallista sekä kestollisesti että käsiteltävän tietomäärän osalta.

Wenin mallin mukaan työmuisti on moniosainen. Jako eri komponentteihin pohjautuu Baddeleyn neliosaiseen malliin (fonologinen silmukka, visuo-spatiaalinen lehtiö, keskusyksikkö ja episodinen puskuri) työmuistista, mutta Wenin malli on hieman laajempi, sillä siinä yhdistyy sekä eurooppalaisen, erityisesti Baddeleyn, että pohjoisamerikkalaisen työmuistitutkimuksen käsitykset työmuistin keskeisimmistä toiminnoista (Wen, 2016, s. 85,87 ). Työmuisti sisältää ensinnäkin säilömuistin aktivoituneen osan (e. $L T-W M$, long-term memory - working memory). Lisäksi työmuistissa on fonologinen silmukka (e. phonological component, PWM; vastaa Baddeleyn phonological loop -käsitettä), joka sisältää kaksi toimintoa: fonologisen lyhytkestoisen varastoinnin (e.phonological short-term store) että artikulatorisen kertaamisen (e. articulatory rehearsal), jolla tarkoitetaan mielessä pidettävän kielellisen informaation kertaamista joko ääneen tai äänettömästi.

Toisen kielen tutkimuksessa työmuistin keskeinen osa fonologisen silmukan ohella on keskusyksikkö (e. executive component, $E W M$ ), joka vastaa pohjoisamerikkalaisessa tutkimuksessa työmuistikäsitettä (Wen, 2016, s. 88). Keskusyksikkö säätelee tarkkaavaisuutta sekä kontrolloi prosesseja, kuten päivitystä (e. updating), vaihtamista (e. shifting) ja estämistä (e. inhibition) (näistä tehtävistä Miyake \& Friedman, 2012; myös Wen, 2016, s. 86). Keskusyksiköllä on myös ei-toimeenpanevia prosesseja, kuten koodaaminen (e. encoding), vahvistaminen (e. consolidating) ja tiedon palauttaminen (e.retrieval) säilömuistista (Wen, 2016, s. 86, 88).

Kun fonologinen silmukka säilöö ja kertaa kielellistä materiaalia, visuospatiaalinen lehtiö (e. visuospatial sketchpad, VWM) varastoi puolestaan visuaalisista ja spatiaalista tietoa. Kielentutkimuksessa visuospatiaaliseen lehtiöön on keskitytty fonologista silmukkaa vähemmän, mikä selittyy osittain fonologisen tiedon keskeisyydellä kielen prosessoinnissa (Juffs \& Harrington, 2011, s. 140). Episodinen puskuri (e. episodic buffer, $E B$ ) on fonologisen komponentin ja visuospatiaalisen lehtiön rinnalla toimiva työmuistin yksikkö, joka pitää monimodaalisessa muodossa olevaa tietoa väliaikaisessa säilössä (Baddeley, 2000, s. 417). Alun perin episodisen puskurin oletettiin myös yhdistävän tietoa kahdesta muusta alajärjestelmästä ja säilömuistista yhtenäiseksi tapahtumaksi (Baddeley, 2000, s. 417), mutta sittemmin sen on ajateltu olevan passiivinen rakenne, joka tuo esiin muualla yhdistyneen tiedon (Baddeley, 2012, s. 17). Episodisen puskurin toiminnot ovat jääneet toisen kielen tutkimuksessa huomiotta (Baddeley, 2015, s. 26; Juffs \& Harrington, 2011, s. 140).

Wenin malli (eli P/E-malli, e. P/E model; phonological/executive hypothesis) keskittyy kielen omaksumisen ja prosessoinnin näkökulmasta kahden keskeisen yksikön, fonolo- 
gisen silmukan ja keskusyksikön, toimintojen tarkasteluun. P/E-mallin mukaan fonologisella silmukalla ja keskusyksiköllä on erilaiset ja erilliset tehtävät kielitaidon eri osa-alueiden omaksumisessa ja kehityksessä (Wen, 2016, s. 90-91). Kielitaidon alkuvaiheessa fonologisella silmukalla on isompi rooli, koska sen oletetaan olevan yhteydessä uusien fonologisten muotojen omaksumiseen sekä kielellisten jaksojen ja sanaryppäiden säilyttämiseen ja vahvistamiseen. Kun oppijoiden kielitaito kehittyy keskitasolle ja sitä pidemmälle, keskusyksikön merkitys kasvaa, kun sitä käytetään kognitiivisesti vaativien toisen kielen taitojen oppimisessa ja prosessoinnissa. Vastaavasti fonologisen silmukan vaikutus muuttuu epäsuoraksi ja on siten vaikeammin mitattavissa. Kun kielitaidon taso lähestyy natiivin tasoa, työmuistin komponenttien vaikutukset kielitaitoon mahdollisesti vähenevät ja ovat samankaltaisia kuin ensikielen omaksumisessa ja prosessoinnissa (Wen, 2016, s. 110-111).

Wen (2016, s. 64-70) on laatinut luettelon vuosina 1992-2015 tehdyistä empiirisistä tutkimuksista (mukana myös julkaisemattomia väitöskirjoja), joissa on tutkittu työmuistin ja toisen kielen oppimisen välistä yhteyttä. Luettelo sisältää yhteensä 80 tutkimusta, joista suurin osa $(67 / 80)$ on tehty aikuisten parissa; vain 13:ssa osallistujina oli lapsia. Puheen ymmärtämisen ja työmuistin yhteyden tutkimukselle näyttäisi olevan tarvetta, sillä vain 17 tutkimuksessa tutkittiin ymmärtämistaitoja, ja näistä mahdollisesti vain muutamaan tutkimukseen (Andersson, 2010; Andringa, Olsthoorn, van Beuningen, Schoonen \& Hulstijn, 2012; Brunfaut \& Révész, 2015; Gu \& Wang, 2007; Kormos \& Sáfár, 2008) sisältyi toisen kielen kuuntelun tutkimusta. Niin Wen (2016, s. 100) kuin Brunfaut \& Révész (2015, s. 147) toteavat, että työmuistin ja toisen kielen kuuntelun suhteesta tarvitaan lisää tutkimusta. Myös Gu \& Wang (2007, s. 46) ovat sitä mieltä, että työmuistin roolia puheen ymmärtämisessä ei ole tutkittu tarpeeksi. Suomessa työmuistin ja vieraan kielen oppimisen yhteyksiä on tutkittu jonkin verran (esimerkiksi Miettinen, 2004, 2012; Service, 1987, 1989, 1992; Service \& Kohonen, 1995), mutta työmuistia ja puheen ymmärtämistä on tarkastellut vain Service (1987). Työmuistin roolia suomen kielen oppimisessa on sivuttu ainoastaan Taina Tammelin-Laineen väitöskirjassa (2014), jossa tutkittiin lukutaidottomien aikuisoppijoiden suomen kielen kehitystä. On siis ilmeistä, että tutkimusta työmuistin roolista puheen ymmärtämisessä tarvitaan lisää, ja tämä artikkeli vastaa osaltaan tähän tarpeeseen ja antaa samalla alkusysäyksen puheen ymmärtämisen ja työmuistin yhteyden laadulliselle tarkastelulle suomi toisena kielenä -kontekstissa.

\section{TUTKIMUKSEN TOTEUTUS}

\subsection{Osallistujat}

Tutkimukseen osallistui 12 aikuista suomenoppijaa, jotka opiskelevat tutkimuksen tekohetkellä kotoutumiskoulutuksessa pääkaupunkiseudulla. Osallistujat ovat tulleet Suomeen vuosien 2013-2015 aikana. Suurin osa (9/12) osallistujista on hitaasti etenevän opintopolun opiskelijoita, joilla oppimista voivat hidastaa esimerkiksi puutteelliset opiskeluvalmiudet tai latinalaisilla aakkosilla heikko luku- ja kirjoitustaito. Vain kaksi osallistujista opiskeli tutkimuksen aikana peruspolulla, jolle ohjataan, jos on perusopiskeluvalmiudet, toiminnallinen luku- ja kirjoitustaito latinalaisilla aakkosilla sekä kokemusta vieraan kielen opiskelusta. Yksi osallistuja oli opiskelijana luku- ja kirjoitustaidon kolmoskurssilla (Luku 3), jolle hän oli palannut hitaasti etenevän polun A-kurssin jälkeen. Kolme osallistujista on käynyt lukutekniikkaa ja opiskelutaitoja vahvistavan LK semi -kurssin ennen hitaasti eteneviä kursseja. (Eri poluista 
ks. Koto-ops 2012, s. 14.) Kahdeksan opiskeli osallistumishetkellä hitaasti etenevällä B-kurssilla, jolla opiskelevien kielitaito on tavallisesti tasolla A1.3-A2.1. Kielitaitoprofiili voi olla tosin epätasainen; tyypillisesti suullinen kielitaito on kirjallista parempi, etenkin niillä opiskelijoilla, jotka ovat tulleet hitaasti etenevälle kurssille luku- ja kirjoitustaidon kursseilta. Kielitaidon tasoa ei testattu ennen tutkimusta, mutta tutkimuksessa käytetyissä kuuntelutehtävissä suoriutuminen antoi viitteitä osallistujien puheen ymmärtämisen taitotasosta.

Osallistujien koulutustaustat ovat keskenään hyvin erilaisia: osallistujista kolme on käynyt peruskoulua kuusi vuotta, yhdellä on peruskoulutausta, kolme on käynyt peruskoulun ja tehnyt sen jälkeen toisen asteen opintoja joko lukiossa tai ammattikoulussa (vain yksi näistä valmistunut ammattiin). Neljällä osallistujalla on takanaan peruskoulun ja lukion lisäksi korkeakouluopintoja, ja näistä neljästä kahdella on alempi korkeakoulututkinto suoritettuna.

Osallistujista suurin osa on tullut Suomeen joko Irakista (6/12) tai Syyriasta (5/12). Näiden lisäksi yksi osallistuja on kotoisin Marokosta. Osallistujien äidinkieli on yhtä lukuun ottamatta arabia; hänen äidinkielensä on kurdi, mutta arabiankielisen tulkin mukaan hän puhuu arabiaa natiivin lailla. Osallistujat ovat keskenään eri-ikäisiä: vanhin osallistujista on syntynyt vuonna 1963 ja nuorin vuonna 1994. Osallistujista naisia oli neljä ja miehiä kahdeksan.

\subsection{Kuuntelutehtävät}

Kuuntelutehtävät ovat peräisin Testipisteen lähtötasotestistä, joka on alun perin laadittu ESR-rahoitteisen Kotoraide - aikuisten maahanmuuttajien alkuvaibeen objaus ja polutus 2008-2010 -hankkeessa ja jota käytetään ja kehitetään tilastoanalyysien pohjalta edelleen.
Testipiste on Helsingissä sijaitseva aikuisten maahanmuuttajien kielitaidon arviointikeskus, jossa arvioidaan maahanmuuttajien suomen kielen lähtötaitotaso ja ohjataan heidät sopivalle suomen kielen kurssille. Kuunneltavia tekstejä oli kolme, joista jokaisessa on neljä osiota, eli yhteensä 12 osiota. Tehtävät sijoittuvat Eurooppalaisen viitekehyksen asteikolla tasoille A1-B1, kuitenkin pääosin tasolle A2.2. Tarkoituksena oli valita sellaisia tehtäväkokonaisuuksia, joista löytyisi jokaiselle osallistujalle vaikeita kohtia mutta joista kuitenkin jokainen ymmärtäisi jotain.

Kuunneltavista teksteistä ensimmäinen sijoittuu lounasravintolaan, jossa asiakas (nainen) keskustelee myyjän (mies) kanssa. Toinen kuunteluteksti sisältää kaksi lyhyttä puhelua, joista ensimmäisessä nainen soittaa naapurille (mies) ja valittaa melusta ja toisessa kodinkoneliikkeen myyjä (mies) soittaa asiakkaalle (nainen) sopiakseen uuden jääkaapin kotiinkuljetuksesta. Kolmannessa kuuntelutekstissä lehden tilaaja (mies) soittaa asiakaspalveluun asiakaspalvelijalle (nainen) ja peruu lehtitilauksensa. Kaikki kuuntelutekstit ovat dialogeja arkipäiväisistä tilanteista. Jokaisessa puhujina on mies ja nainen, jotta kuulija erottaa äänet helposti toisistaan. Dialogit ovat käsikirjoitettuja, joten puhuttu kieli ei ole aivan autenttista, mutta ne sisältävät kuitenkin puhutulle kielelle tyypillisiä piirteitä, kuten äänteiden assimiloitumista ja elisiota.

Testipisteen testissä näiden tekstien ymmärtämistä mitataan monivalintatehtävillä. Jokaista kuuntelutekstiä kohden on neljä osiota (kahdesta puhelusta koostuvassa tehtävässä on kaksi osiota yhtä puhelua kohden), joissa jokaisessa on kolme vastausvaihtoehtoa, joista valitaan joko a, b tai c. Tehtävien ohjeistukset ja osiot ovat suomeksi, eli osallistujien toisella kielellä. Koska tässä tutkimuksessa ei ollut tarkoitus testata osallistujien puheen ymmärtämisen taitoa, käytettiin arabiankielistä tulkkia varmistamaan jokaisen osallistujan kanssa, 
että he ymmärsivät ohjeistukset ja tehtävien kysymykset ennen tekstin kuuntelua. Lisäksi tulkki varmisti monivalintatehtävien osalta, että jokainen osallistuja ymmärsi eri vaihtoehdot. Tekstit kuunneltiin ensin kokonaan ja sitten osissa, ja vasta toisella kuuntelukerralla vastattiin kysymyksiin.

Tutkimuksessa päätettiin kokeilla erilaisia vastaustapoja, jotta osallistujien ymmärtäminen ja toisaalta ymmärtämisvaikeudet saataisiin varmasti esiin. Testitehtävien osioista oli laadittu vastaavat avokysymykset, joihin pyydettiin vastaamaan suomeksi kirjoittaen. Tämän jälkeen osallistuja sai kertoa suullisesti arabiaksi, mitä hän oli ymmärtänyt. Tulkki käänsi vastaukset suomeksi. Lopuksi osallistuja vastasi monivalintakysymykseen. Tällä tavalla meneteltiin kaikkien osioiden kohdalla. Tehtävienteko videoitiin.

\subsection{Stimulated recall -menetelmä ja sisällönanalyysi}

Stimulated recall (SR) on introspektiivinen menetelmä, jolla pyritään saamaan esiin se, millaisia ajatusprosesseja liittyy erilaisista tehtävistä tai toiminnoista suoriutumiseen. Taustalla on oletus siitä, että sisäisiä toimintoja on mahdollista tarkastella kuten ulkomaailmaakin ja että ihminen voi jossain määrin päästä käsiksi sisäisiin prosesseihinsa ja kertoa niistä kielellisesti (Gass \& Mackey, 2000, s. $1,17,25)$. Stimulated recall -menetelmässä tutkimukseen osallistujaa haastatellaan toiminnan jälkeen niin, että haastattelussa käytetään virikkeenä tilanteesta tallennettua video- tai ääninauhaa. Näin pyritään siihen, että haastateltava pystyisi muistamaan tilanteen mahdollisimman tarkasti ja kertomaan, mitä hän siinä tilanteessa ajatteli (Patrikainen \& Toom, 2004).

Muistaminen pyritään varmistamaan siten, että haastattelu tehdään mahdollisimman pian tehtävän tai tehtävien suorittamisen jälkeen. Bloom (1954) on menetelmän luotettavuutta tutkiessaan todennut, että mikäli haastattelu tehdään 48 tunnin sisällä tehtävän suorittamisesta, muistetaan tilanne 95 prosentin tarkkuudella. Tämän jälkeen tarkkuus vähenee, kun aikaväli kasvaa (Gass \& Mackeyn (2000 s. 18) mukaan Bloom, 1954 s. 26). SR-menetelmää ovat käyttäneet kasvatustieteen ja läketieteen tutkijoiden ohella toisen kielen tutkijat (Hodgson, 2008). Kielenoppimiskontekstissa tällä menetelmällä voidaan saada tietoa esimerkiksi oppijoiden viestintätilanteissa käyttämistä strategioista (ks. Huang, 2014). Valitsin tämän menetelmän, jotta käsitykseni ongelmista ja niiden taustalla vaikuttavista kognitiivisista prosesseista eivät rajoittuisi ja perustuisi ainoastaan testitehtäväsuorituksien arviointiin ja oppijoiden toiminnan havainnointiin, vaan saisin tietoa siitä, mitä toisen kielen oppijat ajattelevat ja miten he toimivat, kun puheen ymmärtämisessä on ongelmia. Myös toisen kielen kuuntelua tutkivat Goh (2000, s. 56) ja Lynch (2009, s. 25-26) tuovat esiin oppijoiden raporttien tärkeyden vaikeuksien ymmärtämisen kannalta.

Työmuistia mitataan toisen kielen tutkimuksissa erilaisilla kvantitatiivisilla muistisiltatehtävillä (e. WM span tasks), joista yksinkertaisimpia (e. simple memory span tasks) käytetään, kun mitataan fonologisen silmukan kapasiteettia, ja monimutkaisempia tehtäviä (e. complex memory span tasks), kun halutaan puolestaan selvittää keskusyksikön kapasiteettia. (Ks. Wenin (2016, s. 26-39) selonteko erilaisista työmuistia mittaavista testeistä.) Mittaustulokseen vaikuttaa se, millä kielellä testi tehdään. Gassin ja Leen (2011, s. 75) tutkimuksessa työmuistin keskusyksikön kapasiteettia mitattiin ns. lukemista edellyttävällä muistisiltatehtävällä sekä ensikieltä että toista kieltä käyttäen, ja tulokset olivat eri kielillä erilaiset. Gass ja Lee tulkitsivat tämän niin, että työmuistin kapasiteetti on 
sama, mutta kyky hyödyntää tätä kapasiteettia vaihtelee kielitaidon tason mukaisesti. Tämän artikkelin raportoiman tutkimuksen fokuksessa ei ollut työmuistin toiminta tai yksilöiden kapasiteettien vertaaminen kuuntelutehtävissä suoriutumiseen, vaan tarkastelun kohteena oli erityisesti ymmärtämisen vaikeudet. Vaikeuksien laadullinen avaaminen edellytti introspektiivisen menetelmän käyttöä.

Aineistonkeruu kesti kunkin osallistujan kanssa tavallisesti kaksi päivää: ensimmäisenä päivänä kävimme tulkin avustuksella läpi osallistujan taustatiedot ja osallistuja suoritti kolme kuuntelutehtävää (yhteensä 12 osiota). Seuraavana päivänä hän katsoi videonauhalta edellisen päivän suoritustaan, pysäytti nauhan haluamissaan kohdissa ja kertoi arabiaksi siitä, mitä hän ymmärsi tai ei ymmärtänyt ja mitä hän niissä tilanteissa ajatteli. Vain kahden osallistujan kanssa haastattelu tehtiin kahden päivän päästä eikä seuraavana päivänä. Usein osallistujat halusivat kuunnella joitakin kohtia uudestaan ja selvittää, mistä niissä oli kysymys. Haastattelutilanteissa käsiteltiin siten kahta kuuntelukertaa, edellisen päivän kuuntelua, josta raportoitiin, sekä haastattelupäivän kuuntelua, joka saattoi muuttaa osallistujan ajatuksia kuunnellusta tekstistä ja tehtävästä. Haastattelijana kysyin osallistujan raportoinnin jälkeen vielä niistä kohdista ja asioista, jotka tuntuivat merkityksellisiltä ja joista halusin tietää lisää tai varmistaa, olinko ymmärtänyt oikein. Tulkki käänsi osallistujien ajatukset minulle ja minun kysymykseni osallistujille. Myös toinen tutkimuspäivä otettiin videonauhalle, joten jokaiselta osallistujalta on kaksi nauhoitettua kokonaisuutta, joiden kokonaiskesto vaihtelee reilusta kahdesta tunnista vähän yli kolmeen ja puoleen tuntiin. Yhteensä aineistoa kertyi noin kolmekymmentäviisi tuntia.

Olen analysoinut aineistoa sisällönanalyy- silla sekä litteroidessa että litteroinnin jälkeen: olen etsinyt kohtia, joissa ymmärtämisen vaikeus liitetään suoraan tai epäsuorasti muistin toimintaan. Analysoitavia kohtia ei siten ole paikannettu vain osallistujien väärien vastausten pohjalta, sillä osallistujat raportoivat myös sellaisista vaikeuksia aiheuttaneista kohdista, jotka eivät olleet kytköksissä tehtävissä esitettyihin kysymyksiin. Tutkimuskysymysten näkökulmasta merkityksellisten kohtien tulkintaa olen tukenut työmuistin toimintaan ja toisen kielen oppimiseen liittyvällä tutkimustiedolla.

\section{TYÖMUISTIN HAASTEET TOISENKIELISEN PUHEEN YMMÄRTÄMISESSÄ}

Puheen ymmärtäminen omalla ensikielellä on helppoa ja vaivatonta, eikä siihen tule kiinnittäneeksi huomiota, ennen kuin se muuttuu jostain syystä hankalaksi. Sen sijaan toisenkielisen puheen ymmärtäminen on varsinkin kielenopiskelun alkuvaiheessa hankalaa, ja ymmärtämiseen tulee usein eri syistä aukkoja. Seuraavaksi tarkastelen, millaisia työmuistiin liittyviä ymmärtämisvaikeuksia oppijoilla oli kuuntelutehtäviä tehdessään (ja myös niitä reflektoidessaan) ja mikä yhteys oppijoiden raportoimilla vaikeuksilla on työmuistin teoreettiseen viitekehykseen sekä työmuistia ja toisen kielen puheen ymmärtämistä käsittelevään tutkimustietoon. Tarkastelu painottuu luvun alkuun siten, että alaluvussa 4.1 esitetyt, työmuistiin kytkeytyvät pohdinnat esiintyivät osallistujien raporteissa muiden alalukujen pohdintoja yleisemmin.

\subsection{Tarkkaavaisuus kiinnittyy ybteen sanaan tai ilmaisuun}

SR-haastatteluissa osallistujat raportoivat usein, että kun keskittyi yhteen sanaan, muut sanat unohtuivat tai menivät ohi. 
Esimerkki 1.

Jabbar ${ }^{1}$ : joo, unohdin, koska hän alussa sanoi ja minä keskityn, mikä on pyyntö [mitä asiakas pyytää]. minä mietin, mitä tarkoittaa loppu. mihin [loppu-sanaa] käytetään, onko ateria loppu vai loppu-sana. sana joka tulee alussa, että tiedän uudet, ja olen kadottanut sanat, jotka tulevat sen jälkeen. lohikeitto, kinkku ja kolmas, olen unohtanut myös nyt. minä unohdin ne, kun minä yritän miettiä, mitä tarkoittaa loppu.

\section{Esimerkki 2.}

Settar: minä olen [kielitaito] tasolla että mitä tarkoittaa mitä, myyjä. muodostan [lauseen] näin, mutta toinen lause meni ohi ja sen takia en ymmärrä mitään.

Nämä esimerkit kertovat dekoodausprosessista, jossa osallistuja akustisia vihjeitä ja säilömuistissa olevaa kielitietoaan käyttämällä on tunnistanut puhevirrasta sanoja tai ilmauksia ja sen jälkeen hakenut tunnistamilleen sanoille tai ilmauksille säilömuistista merkityksen (dekoodausprosessista Field, 2008, s. 128). Mutta koska alkuvaiheen toisen kielen oppijalla dekoodaus on vielä epävarmaa ja vaatii paljon tarkkaavaisuutta, työmuistiin ei jää tilaa jo kuullun tulkitsemiselle tai sille, että pystyisi pitämään jo kuultua mielessä (Field, 2008, s. 136). Jos dekoodaus olisi automaattistunutta (eikä tietoista ja kontrolloitua, kuten esimerkeissä), osallistuja pystyisi mahdollisesti pitämään mielessä myös muut puhevirrasta erottamansa sanat ja hakemaan niille säilömuistista merkitykset. Myös Gohin (2000) kuullun ymmärtämisen ongelmia tarkastelevassa tutkimuksessa oli yleistä, että

1 Osallistujien nimet on muutettu. oppijat raportoivat unohtaneensa nopeasti sen, mitä olivat kuulleet ja ymmärtäneet, kun keskittyivät kuuntelemaan uusia sanoja. Goh katsoo tämän ongelman johtuvan työmuistin kapasiteetin rajallisuudesta ja liittyvän enimmäkseen niihin kohtiin, kun juuri jäsennettyä osaa seurasi jakso, jossa oli uusia sanoja tai käsitteitä. (Ma. s. 60.)

Toisenkielistä puhetta kuunnellessa jopa tuttujen sanojen prosessoinnissa voi tulla liian kiire, mikäli tarkkaavaisuus kohdentuu uusiin sanoihin, joita yrittää pitää mielessä samalla, kun pyrkii löytämään näille sanahahmoille vastaavuuksia pitkäkestoisesta muistista. Koska uusia sanoja sisältävän puhevirran purkaminen on hidasta, puhe tuntuu nopealta, kuten seuraavassa esimerkissä 3 todetaan:

\section{Esimerkki 3.}

Murad: yleisesti aihe ei ole vaikea, tarkoittaa, on uusia sanoja, joita en hallitse tarkasti, ja en ymmärrä, vaikka toistetaan minulle, en ehdi keskittymään niihin. tämä ensimmäinen [asia]. nopeus, oikeasti nopeus, ja kaikki samalla nopeudella - - mutta on sanoja [joita] voin ymmärtää niissä kaikissa [lauseissa] - - sanoja, joita en tiedä, en ymmärrä nopeuden takia. nyt hän sanoi, ajattelin sanoi tyttö, mutta ehkä hän tarkoittaa eri asiaa. eli tarkoittaa sitä, että vähän nopeus sekoittaa.

Tässä tulee myös hyvin näkyviin se, kuinka herkästi kuultuun jää aukkoja, kun puhe menee eteenpäin eikä jää tarkasteltavaksi, kuten luettava teksti. Kuuntelutehtävissä heikosti suoriutuneiden (alle puolet oikein monivalintavaihtoehdoista) pohdinnat vaikeuksista liittyivät paremmin suoriutuneita useammin puheen nopeuteen, kun taas paremmin suoriutuneet toivat heikompia enemmän esiin sitä, kuinka yhteen sanaan tai ilmaisuun keskitty- 
misen vuoksi tekstiä meni ohi tai unohtui. Tämä saattaa kertoa siitä, kuinka heikommilla on vaikeuksia saada puhevirrasta otetta, kun taas hieman edistyneemmät pystyvät jo pilkkomaan puhetta osiin, tarttumaan sanoihin ja pohtimaan niiden merkityksiä, mikä johtaa valitettavasti siihen, että osa kuullusta tekstistä katoaa työmuistista.

Vaikka työmuistin toiminta on tavallisesti tiedostettavissa (Wen, 2016, s. 23), sen kapasiteetin rajoja ei välttämättä tiedetä tai ymmärretä. Seuraava esimerkki 4 kertoo, että osallistujalle ei ole aina itsellekään selvää, miksi tekstiä on vaikea ymmärtää, vaikka siinä on ollut tuttuja sanoja.

\section{Esimerkki 4.}

Sadek: minä mietin, miksi (nauraa) ne sanat minä tiedän mutta miksi en, en ymmärtänyt. tarkoitan ne ovat tavallisia [tuttuja] sanoja, jotka kuulin nyt, mutta eilen en ymmärtänyt enkä kuullut niitä - - ehkä tapahtui niin että pakenin [ajatus pakeni] tai jotain muuta, en tiedä, mutta se on outoa

Tutun sanan tunnistusta vaikeuttaa osallistujien mukaan puhenopeuden lisäksi tekstissä käytetty taivutusmuoto.

\section{Esimerkki 5.}

Sadek: mitä minä ymmärsin. mitä hän sanoi A-rapusta? - - annan sinulle esimerkin. minä tiedän mitä tarkoittaa rappu. rappu-sana tarkoittaa rakennuksen portaita tai rakennuksen nimeä [viittaa rappukäytävään]. A-rapusta [taivutusmuoto] muutti koko sanan minulle ja sana hävisi, erityisesti kun [puhe] on nopeaa. ehkä jos olisi sanottu hitaasti hitaasti, ehkä voisin ottaa [saada selvää]. nopeus

$$
\text { ja [päätteen] lisäys voi vaikuttaa. }
$$

Tai sitten sanan tunnistamista hidastaa se, että se on puheessa sidottu toiseen sanaan ja että sitomisen vuoksi äänteitä assimiloituu tai jää kokonaan pois.

Esimerkki 6.

Jabbar: oikeasti viime kerralla kun se [kuuntelu] loppui, oli paljon asioita, joita en ehtinyt ymmärtää. mietin, tulevatko ne uudestaan vai ei, ja lisäksi en ehtinyt kuunnella kaikkea. tuntui siltä, että jokainen sana on liimattu toiseen sanaan. on tosi vaikea erottaa. minusta tuntuu, että joskus kaksi sanaa tulee yhdessä, ensimmäinen on toisessa kiinni. vain jos keskityn, niin tiedän, että ne sanat ovat erillisiä, irti toisistaan. tänään kuulen ne selvemmin. voin ymmärtää enemmän, koska kuuntelen toista kertaa

Mikäli osallistujan säilömuistissa on vain sanan kirjoitettu perusmuoto tai kirjakieltä mukaileva, muista sanoista irrallinen sanahahmo, taivutetun tai assimiloituneen sanan haku säilömuistista ei välttämättä tuota tulosta.

\section{2 Ä̈nteellisen samankaltaisuuden vaikutus}

Alkuvaiheen kielenoppijalla sanavarasto on vielä rajallinen, mikä ilmenee siten, että osallistujalle outoja sanoja on kuuntelutehtävien dialogeissa tiuhaan. Tarve ymmärtää kuultua tekstiä on kuitenkin niin suuri, että äänteellisesti samankaltainen outo tai uusi sana saatetaan hahmottaa tutuksi sanaksi. Seuraavassa esimerkissä 7 Jabbar hahmottaa hänelle oudon ilman-sanan elämäksi, jossa on samoja konsonantteja $(/ \mathrm{l} / \mathrm{ja} / \mathrm{m} /)$ mutta jossa on /i/:n sijaan /e/ ja /a/:n sijaan /ä/. Tämä 
kertoo mahdollisesti siitä, että Jabbarin säilömuistissa olevan elämä-sanan vokaaleilla ei ole erottelevaa roolia, vaan erottelutehtävän tekevät konsonantit.

Tutkimuksessaan aikuisten maahanmuuttajien suomen ääntämisestä Aho, Toivola, Karlsson ja Lennes (2016, s. 83) toteavat, että arabiankielisillä alkuvaiheen suomenoppijoilla oli (etuvokaaleja /i/ ja /y/ lukuun ottamatta) vaikeuksia suomen vokaalien ääntämisessä: esimerkiksi /e/ äännettiin joskus suppeana kuten suomen /i/,ja /a/äännettiin kuten suomen /ä/ ja toisin päin. Ensikieli vaikuttaa toisen kielen ääntämiseen, mutta se voi rajoittaa myös äänteiden havaitsemista. Vandergriftin ja Gohin (2012, s. 41) mukaan varsinkin toisen kielen oppimisen alkuvaiheessa oppijan ensikieli vaikuttaa siihen, mitä äänteitä akustis-foneettinen prosessori havaitsee. Aikuisilla ovat säilyneet vain ne foneettisten piirteiden tunnistimet, jotka ovat heidän ensikielensä aktivoimia (Rost, 2011, s. 39). Esimerkissä 7 Jabbar ihmettelee itsekin, miksi dialogissa puhutaan yhtäkkiä elämästä; hänelle selviää myöhemmin, että elämän sijaan keskustellaan lohikeitosta, jota toivotaan lounasravintolassa ilman valkosipulia.

Esimerkki 7.

Jabbar: esimerkiksi ilma, ja kun hän puhui valkosipulista ja sanoi ilma, tarkoittaa 'elämä', ja kun se tuli tänne, mitä se tarkoittaa. mietin pitkään, miksi tuli.

Alla olevassa esimerkissä 8 kahvila hahmotetaan tutummaksi sanaksi eli kahviksi. On myös mahdollista, että kahvila-sanasta on tunnistettu vain alkuosa.

\section{Esimerkki 8.}

- Voi harmi. Joo, ei tietenkään. Sitten meillä ei taida enää olla oikein mitään tarjottavaa. Tossa kulman takana on lounaskabvila, josta saa täytettyjä leipiä ja salaatteja. Se taitaa olla auki väbän myöhempään. Ehkä sun kannat-

Heithem toistaa suomeksi: salaattia ja leipää, kahvia

Lisäksi esimerkissä 8 esiintyvien ruokasanojen mieleenpalautusjärjestyksessä toteutuu ns. äskeisyysefekti (e. recency effect), jolloin viimeiset kuullut sanat muistetaan heti kuuntelun jälkeen parhaiten, koska niitä ei ole tarvinnut pitää työmuistissa yhtä kauan kuin aikaisemmin esiintyneitä sanoja (esim. Baddeley (2012), joka viittaa tekstissään Glanzeriin (1972); myös Gathercole \& Alloway, 2008, s. 5). Sanojen mieleen palautettu järjestys on sen vuoksi kuunneltuun tekstiin nähden päinvastainen.

\subsection{Muistettavan jakson pituus ylittää työmuistin kapasiteetin}

Työmuistin kapasiteetti kuormittuu alkuvaiheen oppijalla nopeasti, kun muistettavassa jaksossa on mahdollisesti sanoja, joiden merkitystä ei tunne. Mikäli ilmaus tai puhejakso olisi kuuntelijalle semanttisesti mielekäs ja äänneasultaan tuttu, sen tunnistaminen voisi olla automaattistunutta ja sen mielessä pitäminen veisi vähemmän tilaa työmuistin kapasiteetista.

Seuraavassa esimerkissä 9 Heithem kuuntelee haastattelupäivänä kuuntelutehtävien ensimmäistä dialogia. Hän pysäyttää nauhan usein ja yrittää toistaa joitakin kuulemiaan jaksoja osoittaakseen, mikä kohta oli hankala ymmärtää. Lounasaika loppuu melko pian -ilmaisusta Heithemin sanoo vain kaksi sanaa: loppuи peinen. Voi olla, että tarkkaavaisuus kohdentuu ilmaisun loppuun, joka tyypillisesti painottuu alkua enemmän ja 
sisältää tärkeää tietoa, tai sitten lounasaika jää outoutensa vuoksi huomiotta. Sen sijaan loppuu-sana on todennäköisesti tuttu, jolloin Heithem sanoo sen oikein, mutta pian-sanasta tuleepeinen. Äänteellinen dekoodaaminen ei vokaalien osalta onnistu: $i a$-vokaaliyhtymä hahmottuu kuuntelijalla ei-diftongiksi. Melko-sana jää kokonaan keskeltä pois. Sama ilmiö toistuu haastattelussa pian uudelleen. Me suljetaan vajaan puolen tunnin kuluttua on liian pitkä uudelleen toistettavaksi; Heithemin kapasiteetti riittää kahden sanan mittaisen jakson mielessä pitämiseen:puolen kuluttua. Puolen-sana muuttuu osallistujalle todennäköisesti tutumpaan muotoon puoli, joka on sanan perusmuoto.

Esimerkki 9.

$$
\begin{aligned}
& \text { - Hei. } \\
& \text { - Hei. } \\
& \text { - Millanen lounas teillon tänään? } \\
& \text { - No meiän lounasaika loppuu mel- } \\
& \text { ko pian eli - - }
\end{aligned}
$$

Heithem toistaa suomeksi: loppuu peinen Heithem: en ymmärtänyt mitä se - - loppuu tiedän että se on loppuu

\section{- - eli me suljetaan vajaan puolen} tunnin kuluttua.

Heithem toistaa suomeksi: puolen kulu- kuluttua, puoli kuluttua

Saara: puolen tunnin

Tulkki: puolen tunnin tunnin kuluttua (selittää sitten arabiaksi)

Myös seuraavasta esimerkistä 10 huomaa, kuinka fonologisen säilön kapasiteetti on kokonaiselle kysymykselle riittämätön ja kuinka osa ilmauksesta (teillon) jää pois. Lisäksi äänteiden järjestys muuttuu: lounas-sanasta tulee [lomu:sa:], eli /n/:stä tulee /m/, ja se vaihtaa paikkaa / u/:n kanssa, ja -as-lopusta tulee -saa, jolloin /s/-äänne on siirtynyt/a/:n edelle.

Esimerkki 10.

$$
\begin{aligned}
& \text { - Hei. } \\
& \text { - Hei. } \\
& \text { - Millanen lounas teillon tänään? }
\end{aligned}
$$

Heithem: millainen lo- lo- muu saa tenee

Työmuisti joutuu koetukselle myös silloin, kun tekstissä viitataan esimerkiksi pronomineilla johonkin edeltävään lauseeseen tai lauseenosaan. Jos edellistä lausetta ei ole pystynyt toistamaan eikä se ole enää työmuistissa tallessa, viittaussuhde voi jäädä hämäräksi. Seuraavassa esimerkissä 11 Sadek kertoo viittaussuhteiden hahmottamisen vaikeudesta ja toteaa, kuinka lukiessa on kuuntelua paremmin aikaa yhdistää asioita.

Esimerkki 11.

Sadek: nyt kun puhutaan, ehkä syy on pronomini. ne [pronominit] veivät minut [tekstissä] taaksepäin. ne eivät tulleet meille [kurssilla] usein. otimme [opiskelimme] ne nopeasti ja lyhyen aikaa. ja emme ottaneet [opiskelleet] niitä tarkasti. eksyn lauseissa, joissa on pronomineja. tiedätkö miten. esimerkiksi kun sanon sinä tai jotain sellaista. eli pronomini viittaa sanaan, joka tuli ensin. tässä eksyn.

Saara: joo koska siinä täytyy sitten tietää isompi, isompi pätkä

Saara: tietää mihin se $s e$-sana viittaa

Sadek: koska lukeminen, kun luen, voin miettiä sitä [pronominia] ja yhdistää, mutta sellainen kuuntelu ja sillä tavalla on vaikea [yhdistää]

Myös sanojen pituudella on työmuistin kan- 
nalta väliä: koska pitkän sanan toistaminen vie enemmän aikaa kuin lyhyen, on pitkien sanojen muistista katoaminen todennäköisempää kuin lyhyiden. Tätä kutsutaan sananpituusefektiksi (e. word length effect) (ks. esim. Gathercole \& Alloway 2008, s. 6). Efektin taustalla olevista tekijöistä ei olla kuitenkaan täysin yksimielisiä; esimerkiksi Servicen (1998) tutkimuksen mukaan sananpituusefektiä tarkastellessa täytyy ottaa huomioon sanan äänteellinen kompleksisuus. Seuraavissa esimerkeissä 12 ja 13 Heithem yrittää toistaa lähelläkään- ja pahoittelut-sanoja, mutta sanoista jää aina loppu uupumaan, mihin voi vaikuttaa sanan pituuden lisäksi se, että puhuja painottaa sanan alkuosaa.

Esimerkki 12.

- järvee. En oo läbelläkään mitään B-rappua.

- Että niin, jaa-jaa, no

Heithem: lähellä, lähellä, ää lähellä

Esimerkki 13.

- Se ei kyllä onnistu näin jälkikäteen. Paboittelut.

- Mä voin nimittäin saada aika paboja

Heithem: bahel bahe $\mathbf{t}$ bahel

\section{YMMÄRTÄMISTÄ HELPOTTAVIA MUISTITOIMINTOJA}

Osallistujat pystyvät myös auttamaan muistitoiminnoilla puutteellista puhevirran purkamista. Seuraavaksi selvitän, miten oppijoiden raportit liittyvät sellaisiin muistitoimintoihin, jotka kompensoivat työmuistin rajallisuutta ja tukevat puheen ymmärtämistä.

\subsection{Kertaamisen merkitys ymmärtämisen edistämisessä}

Kuuntelutehtävien tekstejä kuunnellessa jotkut opiskelijat toistivat kuultua ääneen (ks. esimerkki 14), jotta se pysyisi mielessä, tai sitten kirjoittivat kuulemansa muistiin mahdollisimman pian (ks. esimerkki 15). Toisin sanoen he tiedostivat jossain määrin oman fonologisen silmukkansa kapasiteetin rajallisuuden ja pyrkivät estämään sanojen mielestä pyyhkiytymistä tietoisen toiston avulla. Kuten jo aikaisemmin todettiin, äänetön tai ääneen tapahtuva kertaaminen on edellytys sille, että kuullut jaksot pysyvät fonologisessa komponentissa ainakin jonkin aikaa (esim. Gathercole \& Alloway, 2008, s. 26; Williams, 2012, s. 428). Varsinkin kun puheeseen voi palata vain rajatusti, on oltava itse aktiivinen ja nopea, jotta sanottu pysyy mielessä.

Esimerkissä 14 Heithem pysäyttää nauhan ja yrittää toistaa, mitä nauhalla sanottiin. Tässä kuullun toisto auttaa pitämään havaitun sanan mielessä, mutta toistettu sana eroaa jossain määrin puhutusta: työpaikalla-sana muuttuu muotoon tuubakkalla. Ilmeisesti Heithemin ensikieli arabia vaikeuttaa vielä toisen kielen vokaalien / $y /$ ja /ö/ sekä diftongien $y \ddot{o}$ ja ai tunnistamista. On myös mahdollista, että Heithem luulee sanan olevan tupakalla, joka voi olla hänelle tutumpi sana taivutettuna kuin työpaikalla. Esimerkissä 15 Settar selittää, että hän kirjoittaa muistiin kuulemaansa, jotta pystyy keskustelemaan vastauksesta myöhemmin.

Esimerkki 14.

No meiän lounasaika loppuu melko pian eli me suljetaan vajaan puolen tunnin kuluttua. Mitä luulet, ehditkö syömään tässä? Tai jos mieluummin syöt kotona tai työpaikalla, niin voin pakata annoksen rasiaan -

Heithem: tuubakkalla 
Saara: työpaikalla

Heithem: tuubakkii

Saara: työ

Heithem: aa

Saara: työ

Heithem: työ

Saara: työ-paikalla työpaikalla

\section{Esimerkki 15.}

Settar: jotta minä en unohda, ensimmäinen asia, kun kuulen sanan, kirjoitan sen ideaksi [jotta muistan idean] eli minä en kirjoita vastausta. kirjoitan että esimerkiksisellainen, vain ideaksi, jotta voin puhua aiheesta. kirjoitan voi harmi, esimerkiksi että saan monta sanaa ideaksi, jotta voin puhua aiheesta. - - että katson ne - - koska jos en kirjoita näin, lause loppuu ja en muista mitään

Alla olevassa esimerkissä 16 Jabbar toistaa ymmärtämänsä sanan merkityksen ensikielellään eli arabiaksi, minkä hän katsoo johtuvan siitä, että hän ei ole vielä sillä tasolla, että ymmärtäisi suoraan suomesta. Ilmeisesti hän kielentää näin sitä, että sanantunnistus ei ole vielä automaattistunutta vaan kontrolloitua, tietoista ja sen vuoksi myös hidasta.

Esimerkki 16.

Jabbar: ei, alussa minä mietin, tarkoitan muistan, olenko ottanut [opiskellut] tämän aikaisemmin vai en. sen jälkeen käännän sen äidinkielelle, koska en ole vielä päässyt sille tasolle, että ymmärrän suoraan suomesta.

Kuullun kertaamista tapahtui myös ihan suunnitellusti. Aineistoa kerättiin osallistujilta kahtena päivänä, joten he kuulivat tekstit yhteensä ainakin neljään kertaan: en- simmäisenä päivänä tekstejä kuunneltiin testitehtävän ohjeistuksen mukaisesti, eli kerran kokonaan ja sitten osissa, ja toisena päivänä SR-haastattelun yhteydessä oli mahdollisuus palata joihinkin kohtiin useampaankin kertaan, mikäli osallistuja niin toivoi. Pyysin osallistujia vertaamaan ensimmäisen ja toisen päivän kuuntelukokemusta toisiinsa. Lähes kaikki vastasivat, että toisena päivänä kuuntelu oli helpompaa tai teksti tuntui selkeämmältä, kuten esimerkeistä 17 ja 18 käy ilmi.

\section{Esimerkki 17.}

Atif: koska nyt, miten nyt, video toistettiin minulle ja lisäksi kysymykset ja vastaukset. se tulee toistettaessa helpommaksi

Muistitoimintojen näkökulmasta tarkasteltuna tässä voi olla kyse siitä, että ainakin jo osa kuullusta tekstistä on ensimmäisen päivän aikana tallentunut säilömuistiin, jolloin jo tallentuneen tekstiosuuden prosessointi on tuttuuden vuoksi vaivattomampaa.

Esimerkki 18.

Farid: nyt ymmärrän dialogin paremmin. eilen ei ollut sama kuin tänään. tänään ymmärsin sen paremmin. ehkä eilen koska oli jotain tai testi tai minulla oli vähän stressiä, mutta nyt ei. ymmärrän dialogin paremmin.

Myös kokemus siitä, kuinka nopeasti tekstissä puhutaan, muuttuu, kun kuuntelukertoja tulee lisää. Tekstiä ehtii kuunnellessa prosessoida enemmän kuin aikaisemmilla kuuntelukerroilla, eli joidenkin sanojen tunnistaminen on nopeutunut tai sitten tekstistä erottuu kuuntelijalle irrallisten sanojen sijaan sanaryppäitä. Alla olevassa esimerkissä 19 osallistuja toteaa, että puhenopeus tuntui toisena päivänä jo normaalilta. 
Esimerkki 19.

Sadek: koska on uusia sanoja, joita nyt puhutaan, en ymmärrä mitä ne tarkoittavat ja puhe on nopeaa, mutta nyt olen huomannut että ei ole niin kova nopeus, mutta viime kerralla oli vähän nopeampi

Toisinaan osallistujat raportoivat kuulleensa jonkun sanan, vaikka myöhemmin paljastuu, että sitä tai edes sitä muistuttavaa sanaa ei ole koko tekstissä. Todennäköisesti tässä on kyse siitä, että jostain tekstissä olleesta sanasta on jäänyt aikaisemmalla kuuntelukerralla mieleen vain sen merkitys, ja myöhemmin tämän merkityksen liittää toiseen sanaan. Alla olevassa esimerkissä Murad sanoo kuulleensa kiinni-sanan, sillä hän on ymmärtänyt niin, että dialogissa esiintyvä ravintola on kiinni. Dialogissa ei käytetä kiinni-sanaa, mutta siinä sanotaan, että meiän lounasaika loppuu melko pian eli me suljetaan vajaan puolen tunnin kuluttua. Ilmeisesti kiinni-sana liittyy Muradin mielessä merkitykseltään joko loppuu- tai suljetaan-sanaan.

Esimerkki 20.

Murad: kuulin, mutta [tänään] hän ei sanonut kiinni. sanoi, ehkä menee kiinni, sanoi, tarkoittaa ehkä menee kiinni. - - mutta ehkä ulkona, tarkoittaa [että] ottaa mukaan kotiin

Saara: joo, ymmärsitkö tän eilen että ravravintola menee kohta kiinni vai kuulitko pelkästään kiinni-sanan

Murad: vain kiinni

Tässä välissä etsitään nauhalta tämä dialogin kohta ja kuunnellaan se uudelleen.

Murad: ei ollut kiinni-sanaa vaan loppu

Saara: niin, niin. oisko se sitten että oisit aikasemmalta kuuntelukerralta, muistanut jonkun, asian, joka liittyy et suljetaan pian tai jot(enkin)

Murad: loppuu ehkä olen ymmärtänyt

Saara: loppuu pian, niin joku semmonen, että yhdistyy sanaan kiinni

Vandergriftin ja Gohin (2012) mukaan ymmärtämisprosessissa kuuntelija rakentaa mielensisäisen representaation siitä, mitä on kuullusta ymmärtänyt ja tallentaa sen säilömuistiinsa. Mentaalinen representaatio ei ole kopio kuullusta tekstistä vaan koostuu muistiin jääneistä sanojen representaatioista. Toisen kielen oppijat, jotka eivät ehkä pysty puutteellisen kielitiedon vuoksi rakentamaan ns. tekstirepresentaatiota (e. text representation), joka kytkeytyy tekstin kirjaimelliseen tulkintaan, muodostavat kuullusta ns. tilannerepresentaation (e. situation representation), mikä tarkoittaa sitä, että he kompensoivat ymmärtämättä jääneitä osia omilla tulkinnoillaan ja odotuksillaan. (Mt. s. 44-45.) Buck (2001, s. 19) kertoo tutkimuksesta (Johnson, Bransford \& Solomon, 1973), jossa todettiin kuuntelijan tekemien päättelyiden yhdistyvän hänen mielensisäiseen representaatioonsa niin, että jonkin ajan kuluttua kuuntelijat eivät pystyneet erottamaan kuullun tekstin sisältöä ja siitä tehtyjä omia päätelmiä toisistaan. Seuraavassa alaluvussa tarkastelen, miten osallistujat hyödynsivät kahta säilömuistin osaa, semanttista ja episodista muistia, yrittäessään muodostaa kuulemastaan mielekästä kokonaisuutta.

\subsection{Semanttinen ja episodinen muisti irrallisten ilmausten yhdistäjänä}

Osallistujat puhuvat SR-haastatteluissa usein "idean rakentamisesta", millä viitataan siihen, että osallistuja muodostaa irrallisista sanoista merkityksellisen kokonaisuuden, jota esimerkiksi Buck (2001) kutsuu ajatusyksiköksi (e. idea unit). Hänen mukaansa ajatuksen jäsen- 
täminen irrallisista sanoista tarkoittaa sitä, että nähdään ilmaisun osien keskinäiset suhteet, esimerkiksi hahmotetaan se, kuka tekee mitä kenelle ja minkä kanssa. (Mt. s. 16.)

Toisinaan osallistujat eivät pystyneet erottamaan puheesta tarpeeksi sanoja, jotta niiden pohjalta voisi rakentaa mielekkään kokonaisuuden, kuten kahdessa alla olevassa esimerkissä 21 ja 22 todetaan:

Esimerkki 21.

Heithem: kabvia, salaattia. joskus. tulee 'joskus', tarkoittaa näin

Tulkki: tarkoitatko että olet ymmärtänyt nämä sanat vai oletko muodostanut niistä idean?

Heithem: en, ymmärsin vain sanoja

Esimerkki 22.

Heithem: en ymmärtänyt kuin muutaman sanan, en muodostanut ideaa. nyt muodostan idean. miksi? koska pysähdyn ja mietin lausetta. nyt muistan mitä missä haluat tarkoittaa, että muistan haluan, ja tarkoittaa, että pysähdyn nyt ja käännän itselleni

Vandergriftin ja Gohin (2012) mukaan ymmärtämisprosessien hahmottamisessa auttaa niiden erottelu alhaalta ylös- (e. bottom-up) ja ylhäältä alas (e. top-down) -prosesseihin. Alhaalta ylös -lähestymistavalla tarkoitetaan prosessointia, jossa dekoodataan eli puretaan puhevirta merkityksellisiin osiin. Kuuntelija käyttää tässä prosessissa hyväksi kielitietoaan, joka koostuu niin fonologisesta tiedosta, sanastosta kuin kieliopillisesta tiedosta kohdekielestä. Tämän lähestymistavan mukaan puheen ymmärtäminen pohjautuu ensisijaisesti puhevirran sisältämälle informaatiolle, eikä kuuntelijan maailmantiedolle. Puhevirran mukana pysyminen on kuitenkin toisen kielen kuuntelijalle mahdotonta, ja siksi hän tarvitsee viestin tulkitsemisen tueksi myös ylhäältä alas -prosessointia, millä viitataan siihen, että ymmärtämisessä hyödynnetään niin tietoa kontekstista kuin maailmantietoa, eli aiemmin kertynyttä tietoa ja kokemuksia asioista. (Mt. s. 18.)

Myös osallistujien raporteista käy ilmi, kuinka he pyrkivät luomaan palasista mielekkään kokonaisuuden oman maailmantietonsa pohjalta. Alla olevassa esimerkissä Settar osoittaa toivovansa, että kuuntelutehtävän ohjeistuksessa annettaisiin tarkempi kuvaus kuunnellun dialogin kontekstista, eikä puhuttaisi vain miehestä, joka soittaa naiselle. Mikäli dialogin osapuoliksi mainittaisiin esimerkiksi veli ja sisko, kuuntelija voisi helpommin muodostaa kehyksen kuunneltavalle tekstille.

Esimerkki 23.

Settar: jos esimerkiksi sanotaan, mies soittaa naiselle, ei ollut sellainen [ei tehdä niin vaan], esimerkiksi jos kirjoitettiin veli soittaa siskolle, esimerkiksi, tai firman kuljettaja soittaa firmalle, tässä voit muodostaa idean, eli kuka soittaa, esimerkiksi siitä tulee idea, mutta näin, miten voin yhdistää, kuka soittaa kenelle

Vandergriftin ja Gohin (2012) mukaan kuuntelijat hyödyntävät puhevirtaa prosessoidessaan aikaisempaa tietoa (sekä maailmantietoa että kokemuksiin perustuvaa tietoa), pragmaattista tietoa, kohdekielen kulttuurista tietoa ja diskurssitietoa, jolla viitataan esimerkiksi tiedon jäsentelyyn teksteissä. Ymmärtäminen alkaa jo siitä, että ennakoidaan kuunneltavan tekstin sisältöä ja sen jälkeen käytetään asiaan liittyvää tietoa hyväksi puhevirran ymmärtämisessä. (Mt. s. 18.) Kuuntelijalle aikaisemmin kertynyt tieto on varastoitunut säilömuistiin asiamuistiosaan, joka jakautuu 
vielä kahteen osaan: semanttiseen muistiin (e. semantic memory) eli tietomuistiin, joka varastoi yleistä maailmaa koskevaa tietoa, ja episodiseen muistiin (e. episodic memory) eli tapahtumamuistiin, johon tallentuvat henkilökohtaiset kokemukset sekä yksittäiset tapahtumat (ihmisen eri muistijärjestelmistä ks. Paavilainen, 2016, s. 166-167). Alla olevassa esimerkissä 24 Murad pohtii eri monivalintavaihtoehtoja ja sulkee pois niitä, jotka eivät tunnu oman maailmantiedon ja kokemuksen pohjalta mielekkäiltä tai mahdollisilta.

\section{Esimerkki 24.}

Murad: ja tämä, kun hän sanoo hänelle mene ja tule toiseen aikaan [viittaa monivalintavaihtoehto c:hen: että asiakas tulee toiseen aikaan] myös [ei käy]. tarkoittaa, että ravintolassa ei voi tehdä näin - - minulle ei ole kertaakaan sanottu ravintolassa, että mene toiseen paikkaan tai mene ja tule myöhemmin. sen takia ensimmäinen vaihtoehto on parempi

Jos omassa elämässä on ollut samankaltainen tilanne kuin kuunneltavassa tekstissä, kuuntelija pystyy hyödyntämään omaa kokemustaan ymmärtämisessä, toisin sanoen käyttämään episodista muistiaan työmuistissa olevan puhejakson tulkinnan tukena. Buckin (2001 s. 18) mukaan kuuntelijan maailmantieto vaikuttaa ymmärtämiseen monella tavalla mutta erityisesti siten, että tieto kontekstista rajoittaa tekstistä tehtävää tulkintaa mutta tieto siitä, miten asiat tavallisesti menevät, täydentää sitä. Alla olevassa esimerkissä 25 käy ilmi, että oma kokemus vastaavasta tilanteesta helpotti Settaria ymmärtämään, mitä dialogissa tapahtui.

Esimerkki 25.

Settar: nyt kun sanottiin kauhea, tiedän, että tarkoittaa 'inhottava' tai 'korkea'. ja kun hän sanoi näin, minä ymmärrän, mitä hän tarkoittaa. sen takia minä sanoin anteeksi [valitsi tämän vaihtoehdon]. on tapahtunut mun kanssa, että naapuri soitti. mistä hän puhui, en ymmärtänyt. mutta siellä tehtiin samoin. minulle on käynyt sillä tavoin. sen takia sanoin sinulle, että se on helppo.

Kuuntelijan hyödyntämä tieto on Vandergriftin ja Gohin (2012, s. 18) mukaan varastoitu säilömuistiin skeeman muodossa. Skeemalla tarkoitetaan "mielensisäistä kompleksista tietorakennetta, joka yhdistää kaiken sen, minkä henkilö tietää ja minkä hän yhdistää tiettyyn käsitteeseen" (Fieldin (2008, s. 216) mukaan Bartlett, 1932). Skeema-käsitettä lähellä on skripti, jolla puolestaan tarkoitetaan johonkin stereotyyppiseen tilanteeseen liittyvää tapahtumasarjaa (Field, 2008, s. 217). Ymmärtämisvaikeuksia voi syntyä, kun kuuntelijan ja puhujan skeemat tai skriptit eroavat toisistaan. Silloin kuuntelijan käsitykset siitä, miten tilanteet yleensä menevät, voivat johtaa vääriin tulkintoihin. Seuraava esimerkki 26 havainnollistaa sitä, kuinka osallistujalla on käsitys siitä, miten kotiinkuljetus tavallisesti hoidetaan, ja se estää häntä ymmärtämästä tekstiä oikein.

Esimerkki 26.

Leila: varmasti kulttuuri vaikuttaa. meillä on, että joku joka tarvitsee jotain, hän [on se] joka soittaa, ei firma soita hänelle. meidän systeemi on näin, että sinä pyydät firmasta, ei firma pyydä ja tuo sinulle. sinä varmistat heidän kanssaan, että sinä pyydät heitä [tuomaan tavaroita]. 


\section{LOPUKSI}

Artikkelissani tarkastelin aineistoa kahden kysymyksen valossa: miten työmuistin rajallisuus tulee esiin oppijoiden kuuntelutehtäväsuorituksissa ja niitä reflektoivissa stimulated recall -haastatteluissa ja millaisilla muistiin liittyvillä toiminnoilla kompensoidaan työmuistin rajallisuutta ja helpotetaan ymmärtämistä? Työmuistin, ja erityisesti sen fonologisen silmukan, rajallisuus tuli selkeästi esiin, kun oppijoiden tarkkaavaisuus keskittyi yhteen sanaan tai ilmaukseen, eikä kapasiteettia riittänyt seuraavien sanojen prosessointiin. Lisäksi fonologisen silmukan rajallisuus tuli näkyviin siinä, kun muistissa pidettävä jakso oli liian laaja oppijan kapasiteettiin nähden. Aineiston tarkastelussa kävi ilmi myös se, kuinka osallistujien ensikielen mukainen ääntäminen hidasti ja vaikeutti sanantunnistusta.

Aineisto näytti myös sen, miten työmuistin rajallisuutta kompensoidaan hyödyntämällä säilömuistissa olevaa tietoa, joka on ollut oppijoilla jo ensikielellä ennen toisen kielen opiskelua. Osallistujat rakensivat ymmärrettyjen sanojen ja ilmausten pohjalta merkityksellisiä kokonaisuuksia, ns. tilannerepresentaatioita, joissa oppija tulkitsee tilanteen niin maailmaa koskevalla tiedollaan kuin kokemuksillaankin. Toisinaan omaan maailmantietoon nojautuminen aiheutti myös vääriä tulkintoja, kun omassa kotimaassa ja kulttuurissa omaksuttu tapa toimia oli erilainen kuin kuuntelutehtävässä esitetyssä puhetilanteessa. Tällaista strategista taitoa olisi hyvä harjoitella ja hyödyntää oppitunneillakin: ennakoida ennen tekstien kuuntelemista, mitä tilanteessa yleensä tapahtuu ja mitä siinä todennäköisesti puhutaan, ja aktivoida oppijalla jo oleva tieto, jotta hän pystyy täydentämään mahdollisimman sujuvasti kuunnellessa vastaantulevia aukkoja.

Tämän tutkimuksen osallistujien kielitaito oli joko alkeistasolla tai alkeis- ja keskitason rajoilla, minkä vuoksi fonologisen silmukan rajallisuuden vaikutus ymmärtämiseen tuli aineistossakin selkeästi esiin. Keskusyksikön toimintojen tai kapasiteetin vaikutusta ymmärtämisen vaikeuksiin oli vaikeampi tunnistaa, mikä saattoi johtua yhtäältä siitä, että monet osallistujista kamppailivat vielä sanastoon liittyvien vaikeuksien kanssa, eivätkä pystyneet suorittamaan kognitiivisesti vaativampia toimintoja, joissa keskusyksikön vaikutus olisi suurempi. Toisaalta keskusyksikön kapasiteetin vaikutusten päättely laadullisesta aineistosta vaatisi laajempaa menetelmällistä pohdintaa ja kokeilua. Fonologisen silmukan toimintaan saa tarttumapinnan paikantamalla muistiin liittyviä kohtia sisällönanalyysin avulla, mutta keskusyksikön monimuotoisen toiminnan kartoittamiseen menetelmä ei riitä. Analyysi vaatisi menetelmällisen kehittelyn lisäksi nykyistä selkeämpää käsitystä keskusyksikön keskeisistä toiminnoista toisen kielen oppimisessa. Wenin mallin mukaan keskusyksikön toiminnalla on yhteys toisenkielisen puheen ymmärtämiseen, mutta se, millainen yhteys on laadullisesta näkökulmasta tarkasteltuna, jää vielä tässä artikkelissa laajalti tunnistamatta.

Artikkelissa esitettyjä tuloksia on vaikea verrata aikaisempiin työmuistin ja puheen ymmärtämisen yhteyttä tarkastelleisiin tutkimuksiin, sillä nämä tutkimukset ovat olleet määrällisiä, ja niissä on analysoitu tilastollisesti työmuistin kapasiteetin (erilaisilla muistisiltatehtävillä mitattuna) yhteyttä puheenymmärtämistehtävissä suoriutumisen kanssa. Esimerkiksi Gun ja Wangin (2007) tutkimuksessa todettiin, että kiinankielisten englanninoppijoiden työmuistin kapasiteetti korreloi kuullun ymmärtämisen testisuoritusten kanssa ja että toisella kielellä tehdyn (keskusyksikön kapasiteettia mittaavan) työmuistitestin tulokset ennustavat osaamista ensikielellä tehtyä testiä paremmin. Kormos ja Sáfár (2008) raportoivat siitä, kuinka un- 
karinkielisten englanninoppijoiden fonologisen silmukan kapasiteetilla oli erilainen rooli A1- ja A2-tasoisten oppijoiden intensiivisessä kielenoppimisessa sekä siitä, että tutkimuksessa käytetty muistisiltatehtävä korreloi hyvin vahvasti yleisen kielitaidon, puhumisen, lukemisen, kirjoittamisen, englannin käytön (sanaston ja rakenteiden osalta) ja myös kuuntelemisen kanssa. Brunfaut ja Révész (2015) tutkivat tehtävän ja kuuntelijan piirteiden roolia toisen kielen kuuntelussa, ja raportissaan he toteavat, että ne kiinalaiset oppijat, joilla oli korkein kapasiteetti sekä fonologisen silmukan että keskusyksikön osalta, saivat parhaimmat tulokset kuullun ymmärtämisen testissä. Andringa ym. (2012) tutkivat natiivien ja ei-natiivien hollanninpuhujien kuullun ymmärtämisen menestystekijöitä ja saivat tulokseksi muun muassa sen, että ei-natiivien kuuntelutaito perustuu eniten lingvistiseen tietoon ja hieman päättelykykyyn mutta työmuistin ei nähty selittävän sitä, miksi toiset menestyvät kuuntelussa toisia paremmin. Viimeksi mainittua tutkimusta lukuun ottamatta aikaisempien tutkimusten tulokset vahvistavat käsitystä varsinkin keskusyksikön kapasiteetin ja puheen ymmärtämisen välisestä yhteydestä, mutta ne eivät tarjoa tietoa siitä, miten nämä kognitiiviset ilmiöt näyttäytyvät oppijoille. Samankaltaisuutta tässä artikkelissa esitettyjen tulosten osalta löytyy eniten Gohin (2000) tutkimuksesta, jossa tarkasteltiin puheen ymmärtämisen vaikeuksia kognitiivisesta näkökulmasta ja jossa osan oppijoiden mainitsemista ongelmista Goh selittää työmuistin rajallisuudella.

Työmuistiin ja toisenkieliseen puheen ymmärtämiseen liittyvien tekijöiden laadullinen tutkiminen on haastavaa, sillä siihen ei ole valmiita malleja, eikä osallistujista kukaan puhu työmuistista eksplisiittisesti, siihen suoraan viitaten. Stimulated recall -menetelmä antoi osallistujille mahdollisuuden pohtia ymmärtämisongelmia ääneen, ja moni kokikin tut- kimuspäivät merkityksellisiksi oppimiselleen. Osallistujien kyky analysoida ja kielentää puheen ymmärtämiseen liittyviä ongelmia vaihteli osallistujien kesken, mutta tätä vaihtelua ei selittänyt koulutustausta tai kuuntelutehtävissä suoriutuminen. Joidenkin osallistujien reflektoinnin vähäisyys ei kuitenkaan vie pohjaa artikkelissa tarkastelluilta tuloksilta, sillä niukkakin reflektointi oli linjassa sisällöltään rikkaampien raporttien kanssa.

Tutkijan näkökulmasta SR-menetelmä teki mahdolliseksi pääsyn osallistujien kokemuksiin ja ajatuksiin pelkän havainnoinnin sijaan. Siinä onkin tämän menetelmän vahvuus: kun määrällisillä menetelmillä voidaan saada tietoa esimerkiksi työmuistin fonologisen silmukan kapasiteetin ja uuden sanaston omaksumisen keskinäisestä yhteydestä, laadullinen ja introspektiivinen lähestymistapa voi antaa tietoa siitä, miten osallistuja kokee ja käsittää sen, kun työmuistin kapasiteetti ei riitä ja kun outo sana tai puhejakso jää yrityksistä huolimatta arvoitukseksi. Gohin (2000, s. 56) mukaan oppijoiden omien raporttien avulla voidaan saada parempi käsitys siitä, miten oppijat ymmärtävät vaikeudet ja miten he asennoituvat niihin. Vain oppijan kokemuksiin ja käsityksiin tarttumalla voidaan löytää oppijan kanssa yhteinen alue, jolla kognitiivisiin ilmiöihin liittyvistä haasteista voidaan keskustella ja mahdollisesti myös niitä ratkaista. Keskustelu voi myös helpottaa kuuntelua, sillä esimerkiksi Vandergriftin ja Gohin (2012, s. 43) mukaan metakognitiivista ja toisen kielen kuunteluun liittyvää tietoa hyödyntämällä kuuntelijat pystyvät ohjaamaan kognitiivisia prosessejaan tehokkaammin. Jatkossa olisi kiinnostavaa yhdistää laadullinen ja määrällinen tutkimusote ja tarkastella esimerkiksi sitä, missä määrin ja miten alkeisoppijan työmuistin kapasiteetti (sekä ensikielellä että toisella kielellä mitattuna) näkyy oppijan raportoinnissa.

Tässä artikkelissa huomio on kohdentunut 
ymmärtämisprosessissa erityisesti sanantunnistukseen liittyviin ongelmiin, jotka ovat alkuvaiheen oppijoille ominaisia ja joista oppijatkin pystyvät raportoimaan hyvin konkreettisin esimerkein. Monet toisenkielisen kuuntelun tutkijat korostavat sanantunnistuksen automaattistamisen tärkeyttä opetuksessa (esim. Buck, 2001; Field, 2008; Rost \& Wilson, 2011), ja sen harjoittelu auttaisi erityisesti työmuistin rajallisuuden kanssa kamppailevaa alkuvaiheen oppijaa. Kun prosessoinnista tulee nopeaa ja tehokasta, työmuistin rajallisuus ei enää kuormita ymmärtämistä.

Työmuistin rajallisuus ei kuitenkaan selitä kaikkia ymmärtämiseen liittyviä vaikeuksia, vain osan niistä. Yksi kiinnostava ja mahdollinen vaihtoehto ymmärtämisongelmien tarkasteluun olisi keskittyä tätä artikkelia laajemmin äänteiden havaitsemisen vaikeuteen ja tutkia esimerkiksi sitä, millainen yhteys suomenoppijoiden ääntämisellä on suomen kielen äänteiden ja sanojen havaitsemiseen. Olisi kiinnostavaa paneutua jatkossa myös siihen, millainen vaikutus tehostetulla ääntämisen ja kielen prosodisten piirteiden harjoittelulla olisi alkeisoppijoiden puheen ymmärtämisen kehittymiseen. Lisää tutkimusta tarvittaisiin siitäkin, miten emootiot, erityisesti kuuntelutehtäviin liitetty ahdistuneisuus, vaikuttavat ymmärtämiseen tai miten kriisialueilta tulleiden suomenoppijoiden huoli oman maan tilanteesta vaikuttaa kielenoppimiseen ja siihen, miten oppija pystyy kuuntelutilanteissa keskittymään.

\section{LÄHTEET}

Aho, E., Toivola, M., Karlsson, F. \& Lennes, M. (2016). Aikuisten maahanmuuttajien suomen ääntämisestä. Puhe ja kieli, 36, 77-96.

Andersson, U. (2010). The contribution of working memory capacity to foreign language comprehension in children. Memory, 18, 458-472.
Andringa, S., Olsthoorn, N., van Beuningen, C., Schoonen, R. \& Hulstijn, J. (2012). Determinants of success in native and non-native listening comprehension: An individual differences approach. Language Learning, 62, 49-78.

Baddeley, A. (2000). The episodic buffer: A new component of working memory? Trends in $\mathrm{Cog}$ nitive Sciences, 4, 417-423.

Baddeley, A. (2003). Working memory and language: An overview. Journal of Communication Disorders, 36, 189-208.

Baddeley, A. (2012). Working memory: Theories, models, and controversies. Annual Review of Psychology, 63, 1-29.

Baddeley, A. (2015). Working memory in second language learning. Teoksessa Z. Wen, M. Borges Mota \& A. McNeill (toim.), Working memory in second language acquisition and processing, (s. 17-28). Bristol: Multilingual Matters.

Bartlett, F. (1932). Remembering (uusintapainos 1995). Cambridge: Cambridge University Press.

Brunfaut, T. \& Révész, A. (2015). The role of task and listener characteristics in second language listening. TESOL 2uarterly, 49, 141-168.

Bloom, B. (1954). The thought processes of students in discussion. Teoksessa S. French (toim.), Accents on teaching: Experiments in general education, (s. 34-46). New York: Harper.

Buck, G. (2001). Assessing listening. Cambridge: Cambridge University Press.

Cowan, N. (2014). Working memory underpins cognitive development, learning, and education. Educational Psychology Review, 26, $197-$ 223.

Field, J. (2008). Listening in the language classroom. Cambridge: Cambridge University Press.

Gass, S. \& Mackey, A. (2000). Stimulated recall methodology in second language research. New York: Routledge.

Gass, S. \& Lee, J. (2011). Working memory capacity, inhibitory control, and proficiency in a second language. Teoksessa M. Schmid \& W. Lowie (toim.), Modeling bilingualism: From structure to chaos, (s. 59-84). Amsterdam: John Benjamins Publishing Company.

Gathercole, S. \& Alloway, T. (2008). Working memory \& learning. A practical guide for teachers. Los Angeles: Sage.

Glanzer, M. (1972). Storage mechanisms in re- 
call. Teoksessa P. Bower (toim.), The psychology oflearning and motivation: Advances in research and theory, (s. 129-193). New York: Academic.

Goh, C. (2000). A cognitive perspective on language learners' listening comprehension problems. System, 28, 55-75.

Gu, S. \& Wang, T. (2007). Study on the relationship between working memory and EFL listening comprehension. CELEA Journal, 30, 46-56.

Hodgson, V. (2008). Stimulated recall. Teoksessa R. Thorpe \& R. Holt (toim.), The SAGE dictionary of qualitative management research, (s. 212-213). Lontoo: Sage Publications.

Huang, L.-S. (2014). Video-stimulated verbal recall: A method for researching cognitive processes and strategic behaviors. Sage Research Method Cases. Lontoo: Sage Publications.

Johnson, M., Bransford, J. \& Solomon, S. (1973). Memory for tacit implications of sentences. Journal of Educational Psychology, 98, 203-205.

Juffs, A. \& Harrington, M. (2011). Aspects of working memory in L2 learning. Language Teaching, 44, 137-166.

Kormos, J. \& Sáfár, A. (2008). Phonological shortterm memory, working memory and foreign language performance in intensive language learning. Bilingualism: Language and Cognition, 11, 261-271

Koto-ops $2012=$ Aikuisten maahanmuuttajien kotoutumiskoulutuksen opetussuunnitelman perusteet 2012. (2012). Määräykset ja ohjeet 2012:1. Helsinki: Opetushallitus.

Laakso, S. (2015). Alkuvaiheen S2-oppijoiden käsityksiä puheen ymmärtämisen vaikeuksista ja kompensaatiostrategioista. Teoksessa T. Jakonen, J. Jalkanen, T. Paakkinen \& M. Suni (toim.), Kielen oppimisen virtauksia. Flows of language learning. AFinLAn vuosikirja 2015, (s. 91-112). Soveltavan kielitieteen yhdistyksen julkaisuja n:o 73. Jyväskylä: Suomen soveltavan kielitieteen yhdistys AFinLA.

Lynch, T. (2009). Teaching second language listening. Oxford: Oxford University Press.

Miettinen, H. (2004): Fonologinen työmuisti ja kielen oppiminen: Katsaus aiempaan tutkimukseen. Teoksessa P. Muikku-Werner \& H. Stotesbury (toim.), Minäja kielitiede - soveltajan arki. AFinLAn vuosikirja 2004, (s. 13-28). Suomen soveltavan kielitieteen yhdistyksen julkaisuja n:o 62. Jyväskylä: Suomen soveltavan kielitieteen yhdistys AFinLA.

Miettinen, H. (2012). Phonological working memory and L2 knowledge. Finnish children learning English. Väitöskirja. Jyväskylä Studies in Humanities 184. Jyväskylä: Jyväskylän yliopisto.

Miyake, A. \& Friedman, N. (2012). The nature and organization of individual differences in executive functions: Four general conclusions. Current Directions in Psychological Science, 21, 8-14.

Paavilainen, P. (2016). Toimivat aivot. Kognitiivisen neurotieteen perusteita. Helsinki: Edita.

Patrikainen, S. \& Toom, A. (2004). Stimulated recall - opettajan interaktiivisen ajattelun ja toiminnan tutkimisen menetelmä. Teoksessa P. Kansanen \& K. Uusikylä (toim.), Opetuksen tutkimuksen monet menetelmät, (s. 239-260). Jyväskylä: PS-kustannus.

Rost, M. (2011). Teaching and researching listening (2. painos). Harlow, England: Pearson Education.

Rost, M. \& Wilson, J. (2013). Active listening. Harlow, UK: Pearson Education Limited.

Service, E. (1987). Applying the concept of working memory to foreign language listening comprehension. AFinLAn vuosikirja 17 (1987), (s. 81-90). Suomen soveltavan kielitieteen yhdistyksen julkaisuja n:o 45. Jyväskylä: Suomen soveltavan kielitieteen yhdistys AFinLA.

Service, E. (1989). Phonological coding in working memory and foreign-language learning. Helsinki: Helsingin yliopiston, yleisen psykologian osasto.

Service, E. (1992). Phonology, working memory and foreign-language learning. Quarterly Journal of Experimental Psychology, 45, 21-50.

Service, E. (1998). The effect of word length on immediate serial recall depends on phonological complexity, not articulatory duration. 2uarterly Journal of Experimental Psychology, 51 A, 282-304.

Service, E. \& Kohonen, V. (1995). Is the relationship between phonological memory and foreign language learning accounted for by vocabulary acquisition? Applied Psycholinguistics, 16, 155-172.

Tammelin-Laine, T. (2014). Aletaan alusta. Lukuja kirjoitustaidottomat aikuiset uutta kieltä oppimassa. Väitöskirja. Jyväskylä Studies in Hu- 
manities 240. Jyväskylä: Jyväskylän yliopisto. Vandergrift, L. \& Goh, C. (2012). Teaching and learning in second language listening. Metacognition in action. New York: Routledge.

Wen, Z. (2016). Working memory and second language learning. Towards an integrated approach. Bristol, Buffalo: Multilingual Matters.
Williams, J. (2012). Working memory and SLA. Teoksessa S. Gass \& A. Mackey (toim.), The Routledge handbook of second language acquisition, (s. 427-441). New York: Routledge. 


\section{HOW LIMITED WORKING MEMORY ACCOUNTS FOR LISTENING COMPREHENSION PROBLEMS OF L2 FINNISH LEARNERS}

Saara Laakso, The Centre for Applied Language Studies (CALS)

In this article, I will examine the connection between the constraints of working memory and the comprehension problems of L2 Finnish listeners by exploring the learners' listening task performance and the following stimulated recalls. Additionally, I will discuss what kind of memory functions make understanding easier and compensate for the limitations of working memory. The participants were 12 Arabic speaking adult Finnish learners of elementary and basic levels of proficiency, and the data consists of video recordings of their listening tasks and stimulated recalls.

The limitations of working memory affected participants' comprehension problems particularly when focusing on one word or phrase resulted in forgetting the preceding or following words, and when the length of the speech unit to remember exceeded the participant's working memory capacity. The participants improved their own understanding and compensated for the constraints of working memory via top down processing - by filling the gaps in the text with the help of experiences and knowledge of the world from their long-term memory.

Keywords: Finnish as a second language, listening comprehension, second language learning, stimulated recall, working memory 